\title{
The Origin of Eastern \& Western Management Ideas and Research Prospect
}

\author{
Yaling Li \\ Business and Tourism Management School, Yunnan University, Kunming, Yunnan, China \\ 1401321642@qq.com
}

Keywords: eastern management ideas, western management ideas.

\begin{abstract}
Oriental management theory originated from the excellent traditional culture of the orient. Western management theory originated from the philosophy of ancient Greece. In addition to the deep philosophical origin of ancient Greece, it is more important to rely on the development of science and technology since modern times. Because they are closely related to the different philosophical backgrounds and social and cultural backgrounds. East and western management ideas have their own characteristics and advantages.
\end{abstract}

\section{Introduction}

Management ideas are generic terms of views, thoughts and opinions because of thinking about management activities in social practice. They are self-conscious and systematic images formed from a variety of social relationship and contradictory activities. The gradual formation and development of management ideas are based on management activity practice, which have went through the process of thought germination, formation, systematize and deepen constantly. The formation and evolution of management ideas are influenced by many factors, therefore, the different cultural tradition and value background between the East and West have determined their different methods and thoughts in management, and they developed, perfected and matured continuously under different social and culture background, then they have formed management idea system with different characteristics, these existences of difference have not influenced the eastern and western management ideas to give play to their own advantages.

\section{The philosophical origin of oriental management theory}

Oriental management theory originated from the excellent traditional culture of the orient. Most of the scholars think its theoretical origin is mainly the orthodox idea of ancient china-the kindheartedness theory of Confucianism, in addition, it also include yin-yang theory from the book of changes, govern without intervention of Taoists, advocating law theory of Legalists, choose and employ person theory of military strategist and other traditional, excellent management culture like universal love, harmony, respecting the scholars, at the same time It have also absorbed the rational management culture elements from charity theory of Buddhism. It maybe said the contents are extensive and profound, the thoughts are quintessential and profound, these philosophical ideas have constituted the theoretical origin of Oriental management theory, and develop a school of it's own with unique charm.

China and Japan are the representative of Oriental management ideas, the main feature is based on China traditional culture, use many thinking modes of philosophy, carry out mainly humanistic thought, also emphasize organizational culture, harmony relationship, closely connection and strong sense of community. At a process of decision making, the decision of decision maker made a big difference for the process, explicitly subjective. The founder of Oriental management school of thought $\mathrm{Mr}$. Su dongshui have put forward that the core idea of Oriental management theory are "prioritizing people, exemplifying virtues, conducting oneself to serve others", and took them as the core, then he have creatively come up with five conducts: .philosophy, psychology, relations with 
people, laying plans, talent". The philosophy of Oriental management is a philosophical ideological system including the value, ethic and acquaintanceship of man as the core, It's one of the important contents about Oriental management ideological system also a management philosophy theory about meaning of human life, life ideals and the basic norm of human life.

\section{The philosophical origin of western management theory}

The philosophy of western management originated from the philosophy of ancient Greece. As a nation of commercial city-states, the development of ancient Greek culture formed the unique humanistic spirit of the early human civilization. The pursuit of individual independence and liberation, which is the essential feature of ancient Greek culture, then began to sprout in the Renaissance, and the establishment of capitalist system made it a great development. Finally it has formed at the end of 19th century and early 20th century and tended to mature after World War II, then It has been a rich development after 1980s. After the early germination of management thought, the Western management thought was more scientific. Entering the period of classical management theory, It payed more and more attention to the study of human nature, and then came into the period of behavioral science and the theoretical period of modern management.

Contemporary management scholars generally divide the development of western management thought into three stages, namely, the period of "classical management theory", the period of "general management theory" and "modern management theory" period. But from the point of view of the change of philosophy, it can be divided into three periods: first, positivist philosophy of management theory, The understanding of people in this period was still at the stage of "economic man", "tool man", the father of scientific management theory, Taylor, Carl Georg Langer Barth, Henry Laurens Gantt and others have tried to improve efficiency through technical analysis, charts, and psychological research in research activity and management theory. So they are called "efficiency experts". Second, it's the philosophical management theory of "power contingency in system". With the development of society, people find that the management ideas of scientism and advocating technology can't solve the bottleneck problem of the poor continuous improvement of production efficiency in management practice. Therefore, people began to turn to the study of the material environment of management, social environment and organizational structure, also leaded the system view, movement view and concept of development into the management practice, people have realized that management is a system of movement, openness and power contingency. With the gradual development of society, both Taylor's Theory of Scientific Management and Fayol's Theory of organizational Management have been challenged by external factors and internal change of conditions. People generally realized that people, material resources, information and environment and other factors were moving, connecting, developing and changing, the concept of power contingency in system has gradually become the subject of management thinking. Third, it's the "humanism" philosophy management theory. On 1920, with the development of "humanism" which emphasized the "self-consciousness" in the philosophy of the Hegel School of Youth, the study of "human" has gradually become the subject of management research, the subjective status of human has been paid attention to, The viewpoints of "tool man", "biological man" and "economic man" in the period of scientific management theory were replaced by the theory of "social man" in behavioral science, "complex person" in system and contingency theory, and "social person" theory. The "materialistic orientation" was replaced by "humanism", the research of management also changes from pure scientific, technical, rational field to value judgment, value realization field and the thinking of "human nature".

From the origin and development of the above western management ideas, the western management thought has a clear thread and its own system. In addition to the deep philosophical origin of ancient Greece, it is more important to rely on the development of science and technology since modern times. Western management scholars have been looking for the innovation and 
breakthrough of the management model with the process of continuous economic change and formed the western management theory, which was based on the theoretical foundation and practical experience. It was generally accepted by the academic circles that the western management begin with classical management theory of Taylor, which was based on the hypothesis of "economic man", valuing things rather than people, People are only regarded as tools to realize economic benefits, and then western management has developed into the behavioral science management theory represented by Mayo and Maslow. The theory began to focus on the role of human psychological factors in management, so it was based on the hypothesis of "social man" and researched the potential impact of human emotional factors on economic activities through numerous experiments. After the behavioral science management theory, because the western economy developed rapidly, the economic environment was complex and changeable, the management theory appeared new development, finally developed to the modern western management science.

\section{Research prospect}

From the available literature, there are many areas which are worthy of further study and exploration, it is manifested in the following aspects. First, as for the comparison of difference of Chinese and western management, it is mainly from the qualitative analysis and elaboration about development history of management thought of the east and the west, to some extent it is generalized perceptual knowledge and concept analysis, but it poor at comparing the difference between the east and west management effect from the perspective of quantitative icon by related cases and data in the form, so it has the lack of differences between east and west management factors of further empirical and case studies. Second, the discusses about the integration aspects of the east and west management mostly focused on the static analysis and the expression of ideal, it's highlight to absorb advantages and essence of eastern and western management, seeking common ground while putting aside differences to realize the integration of management in the east and west, but it ignored the scope of application and dynamic understanding of management in the east and west and put forward the rational idea often cannot solve the real conflict between east and west management, with poor practicability. Third, the idealized conception of fusion management in the relevant literature is not widely applied in practice. At present our country enterprise in the management practice, it either advocate such as Europe, America, Japan is western-style management, or promote Chinese management, and the combination of Chinese and western management with practice, to a certain extent, thus it's necessary to further strengthen the innovation of the combination of Chinese and western management mode and successful cases of exploration.

\section{References}

[1] Dong Jingbao, Wang Shangyi. Cultural Analysis of Chinese and Western Management thoughts. [J] .Taiyuan: the study of Productivity, 2000, (4).

[2] Peng he, Su Dongshui. On the Research Boundary of Oriental Management. [J] .Nanchang: academic monthly Journal, 2007, (2).

[3] Su Dongshui. the trend of East and West Management amalgamation and Development in the 21st Century. [J] .Beijing: Xinhua Abstracts 2009, (1).

[4] Zhang Hanxu, On the difference and amalgamation of Eastern and Western Management thoughts. [J] .Taiyuan: a scientific guide, 2014, (15). 